\title{
Erratum to: Effects of imidacloprid, a neonicotinoid pesticide, on reproduction in worker bumble bees (Bombus terrestris)
}

\author{
Ian Laycock - Kate M. Lenthall - Andrew T. Barratt • \\ James E. Cresswell
}

Published online: 22 July 2012

(C) Springer Science+Business Media, LLC 2012

\section{Erratum to: Ecotoxicology}

DOI 10.1007/s10646-012-0927-y

In the original publication of the article, the conversion of imidacloprid concentrations from $\mu \mathrm{g} \mathrm{\textrm {L } ^ { - 1 }}$ into parts per billion ( $\mathrm{ppb}$ ) has been miscalculated in certain sections of the text. The authors would like to correct this error and provide the corrected conversions in the altered text below (correct ppb values given in italics).

- ...exposure to imidacloprid at an environmentally realistic level of $1 \mu \mathrm{g} \mathrm{L}^{-1}(=0.8 \mathrm{ppb}) \ldots$

- ...oocytes were smaller in bees from microcolonies exposed to imidacloprid at $125 \mathrm{gg} \mathrm{L}^{-1}(98 \mathrm{ppb}) \ldots$

- ...syrup dosed with imidacloprid at $1 \mathrm{ppb}(1.28 \mu \mathrm{g}$ $\left.\mathrm{L}^{-1}\right) \ldots$
- ...the strongly detrimental effects of imidacloprid on fecundity at dosages of $39 \mathrm{ppb}\left(50 \mu \mathrm{g} \mathrm{L}^{-1}\right) \ldots$

- Except at relatively high dosages (i.e. above 98 ppb)...

- ...the detrimental effects of imidacloprid on bumble bee fecundity at dosages below $98 \mathrm{ppb} .$.

- ...dietary imidacloprid at levels up to approximately 39 $p p b . .$.

- ...bumble bee workers feeding on syrup at the highest dosage, $98 p p b \ldots$

- ...microcolonies feeding on syrups at dosages of $16 \mathrm{ppb}$ $\left(20 \mu \mathrm{g} \mathrm{L}^{-1}\right) \ldots$

- ...microcolonies exposed to an intermediate dosage of imidacloprid, $39 \mathrm{ppb...}$

- ...imidacloprid at $39 \mathrm{ppb}$ may have disrupted social interactions.

The online version of the original article can be found under doi: 10.1007/s10646-012-0927-y.

I. Laycock $(\varangle) \cdot$ K. M. Lenthall · J. E. Cresswell

Department of Biosciences, College of Life \& Environmental

Sciences, University of Exeter, Hatherly Laboratories,

Prince of Wales Road, Exeter EX4 4PS, UK

e-mail: i1219@exeter.ac.uk

\section{A. T. Barratt}

Department of Mathematics and Computer Science,

College of Engineering, Mathematics and Physical Sciences,

University of Exeter, Harrison Building, North Park Road,

Exeter EX4 4QF, UK 